\title{
The analysis of May 29, 2012 flood phenomena in the lower sector of Slănic drainage basin (case of Cernăteşti locality area)
}

\author{
Romulus COSTACHE ${ }^{1}$ and Remus PRĂVĂLIE ${ }^{*}$ \\ 1 University of Bucharest, Faculty of Geography \\ * Correspondence to: Remus Prăvălie, University of Bucharest, Faculty of Geography, Romania. E-mail: \\ pravalie_remus@yahoo.com.
}

(C2013 University of Suceava and GEOREVIEW. All rights reserved. doi: 10.4316/GEOREVIEW.2013.22.1.64

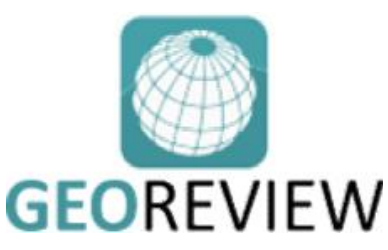

\section{Article history}

Received: April 2013

Received in revised form: July

2003

Accepted: August 2013

Available online: Sept. 2013

\begin{abstract}
This paper aims to analyze, especially in terms of space, the flood phenomenon in Cernăteşti locality, on May 29, 2012. In the context of high intensity torrential rains over a short period of time, in this period occurred flash-floods of high intensity on Slănic river, producing catastrophic floods in Cernăteşti locality. Thus, for a rigorous analysis of spatial occurrence of these hydrological risk phenomena, were used detailed cartographic materials, such as the 1:5000 topographic plans overlapped to the analyzed territory. Also, we analyzed the synoptic conditions directly responsible for the extent of the flooding process, which resulted in disastrous effects on the socioeconomic component. The results certified that, due to the synergy between torrential rainfall and the local morphometry, 60 ha of the Slănic flood plain sector was flooded in the area of Cernăteşti locality, with more than 20 buildings and almost $500 \mathrm{~m}$ of the local accessiblity infrastucture damaged.
\end{abstract}

KEY WORDS: Cernăteşti, Slănic catchment, flash-floods, flooding, socio-economic elements, impact.

\section{Introduction}

In the current stage, the rigorous forecast of hydrological risk phenomena such as floods and flash-floods is a very difficult task. Most of the speciality studies appeals to a range of hydrological models (Reed et al., 2007, Looper \& Vieux, 2012 etc.), meteorological (Koutroulis \& Tsanis, 2010, Villarini et al., 2010 etc.) or hydrometeorological (Alfieri et al., 2012) related to the pattern of manifestation of flash-floods and floods, but these models have a series of drawbacks related to the precise predictability of intensity and frequency of these hydrological risk phenomena. In Romania, many specialty studies regarding surface runoff occurrence on the slopes and its potential to generate flash-floods and floodings, as a consequence, were realized (Bilaşco, 2008; Drobot \& Chendeş, 2008; Mătreaţă\& Mătreaţă, 2010; Teodor \& Mătreaţă 2011; Zaharia et al, 2012 and others). Though, the compelling prediction of the areas with high potential to hidric risk phenomena is limited. Therefore, methodology approach is being continously improved.

At European level, Romania is among the first countries in terms of floods risk along with other countries in Central and South-Eastern Europe (Roo et al., 2007). The main causes of floods are 
linked in most situations to flash-floods that occur upstream of the affected localities. This is also the situation for the area of locality Cernăteşti, described in the present work, an area which was intensely affected by floods in 2012, this event being possible in the synergistic context both of favourable factors from upstream for flash-floods occurrence on Slănic river (later it turns into flooding downstream) and the lack of a viable system of forecasting and warning from the competent authorities.

This paper aims to investigate both synoptic conditions directly responsible for triggering floods phenomena on May 29, 2012 in the locality Cernăteşti, but especially the spatial delimitation of areas affected by these extreme hydrometeorological phenomena with negative impact on socioeconomic elements.

\section{The study area in the context of floods phenomena occurrence}

The study area, space of the Cernăteşti locality, is in the lower sector of Slănic catchment in the vicinity of the confluence of rivers Slănic and Buzău (figure 1). Slănic catchment is part of Buzău catchment and it occupies in the Subcarpathian sector an area of approximately $320 \mathrm{~km}^{2}$. Slănic catchment is predisposed to hydrological risk phenomena such as flash-floods and floods in the synergistic context of favourable factors such as low grade of hydrotechnical arrangement, large slopes with spread potential of flash-floods and flooding in downstream areas, high deforestation, etc.

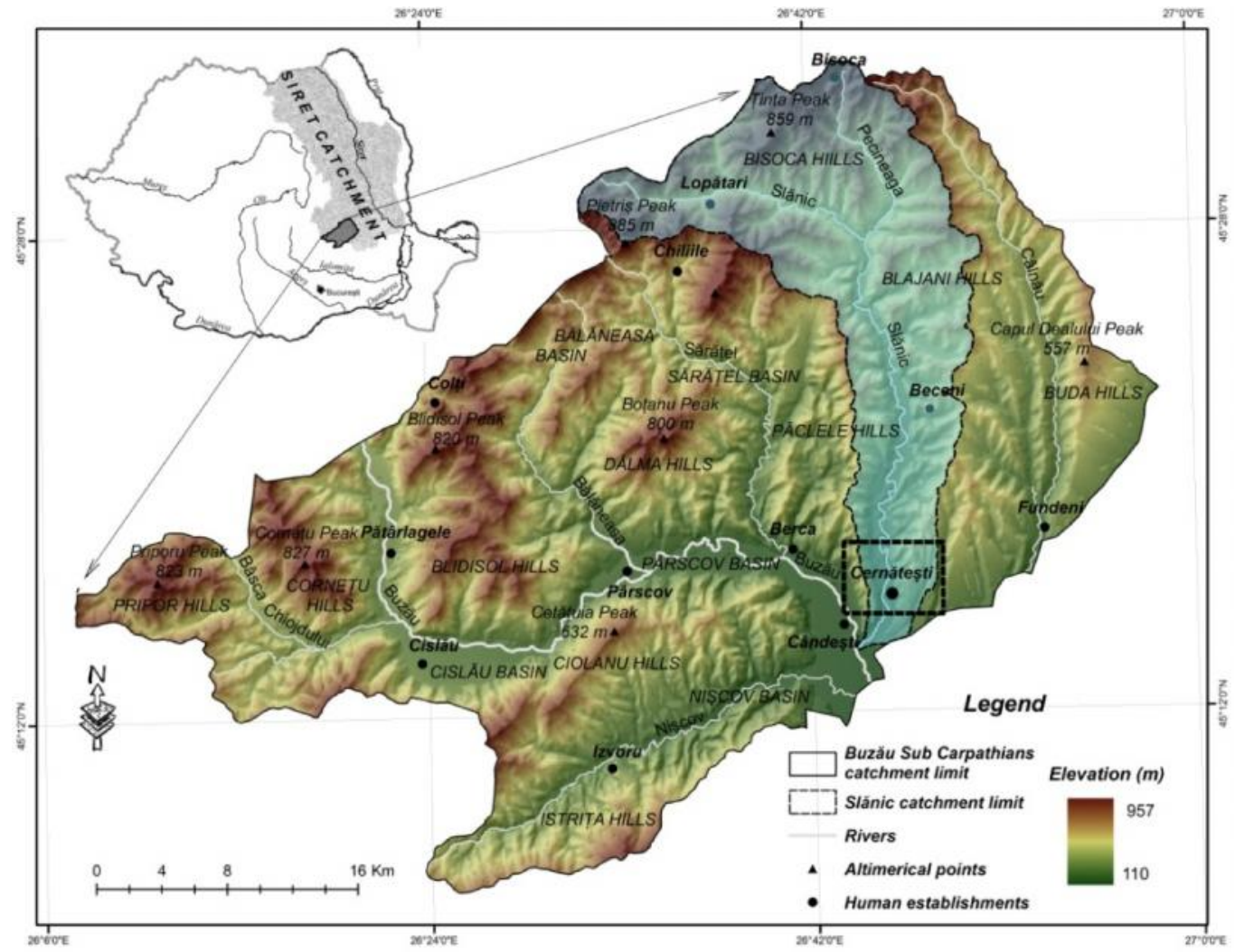


Figure 1. Location of Cernăteşti locality in Slănic catchment. This figure is available in colour online at www.georeview.ro.

A main component that plays an essential role in forming flash-floods and floods is represented by topographical peculiarities. According to some speciality studies, Slănic catchment has among the highest values of surface runoff in entire Subcarpathian sector of Buzău catchment (Costache \& Prăvălie, 2013; Prăvălie \& Costache, 2013). Thus, there is a high potential for triggering flashfloods, especially in the northern sector of the basin, causing to their turn a major potential to trigger flooding downstream. It represent the main cause of the events on May 29, 2012, when, after the occurrence of heavy rains in the upper sector of river Slănic, were triggered floods downstream where the peculiarities of the river bed (bed with small depths and large widths) favored and more the inundability of agricultural and built areas.

The substrate of the study area is generally composed of sandstone, schisty flysch, marl and clay formations, rocks which are generally characterised by low water permeability (Scrădeanu \& Alexandru, 2007) and increase surface runoff. The most important harsh rocks which cause a low water infiltration and surface runoff are Răchitașu sandstones and the schisty flysch. These rocks are found in the upper area of the basin, on a 49,07 sq $\mathrm{m}$ surface.

Slope is one of the morphometric factors that have a decisive role in surface runoff. In Slănic river basin, slopes are high, exceeding $15^{\circ}$ on more than $13 \%$ of its area, especially on the upper area of the basin. Flash-flood waves go towards water accumulation areas, with slope values less $3^{\circ}$ along the major riverbeds of the main water flows. In this case, localities along Slănic river must be mentioned: Lopătari, Mânzălești, Vintilă Vodă, Beceni and Cernătești. Convex surfaces, described by the profile curvature, where surface runoff occurrs, are found on almost $42 \%$ of the total area.

The shape of Slănic sub-basins is also very important for flash-flood waves genesis. The subbasins circularity ratio is high, exceeding 0.55 (Pecineaga, Coca, Plăvăț, Jghiab). The circularity ratio was obtained by applying the following formula: $4 \pi F / P 2$, where $F$ is the basin surface and $P$ its perimeter (Pișota et al., 2010).

According to the land use dinamics in Slănic river basin, forests have considerably decreased during 1990-2006, with almost $4000 \mathrm{Ha}$ (Corine Land Cover 1990, 2006). This is very important for the surface runoff balance, because forest areas have an important role in moderating surface runoff, by interception and water volume diminishing.

\section{Methodology}

In order to analize the metheorological conditions mainly responsible for the flash-floods that occured on the specific date, in a first stage the synoptic atmospheric conditions responsible for the large amount of precipitations on 29 May were analyzed by using data on the relative baric topography between levels of $500-1000 \mathrm{hPa}$ from the european (german) data platform wetter3.de. Data from hydrometric station Cernăteşti about level and flow of Slănic river recorded on 29 May, 2012, were used.

The second stage was to achieve a spatial model of the topography of the land for the space of locality Cernăteşti (figure 1). For a rigorous spatial analysis was used $1: 5000$ topographic plan from mentioned space, being extracted contour lines with an equidistance of $2.5 \mathrm{~m}$. Topographic 
plan, obtained from the National Geodetic Fund, represented the basic support in spatial modeling of floating surfaces.

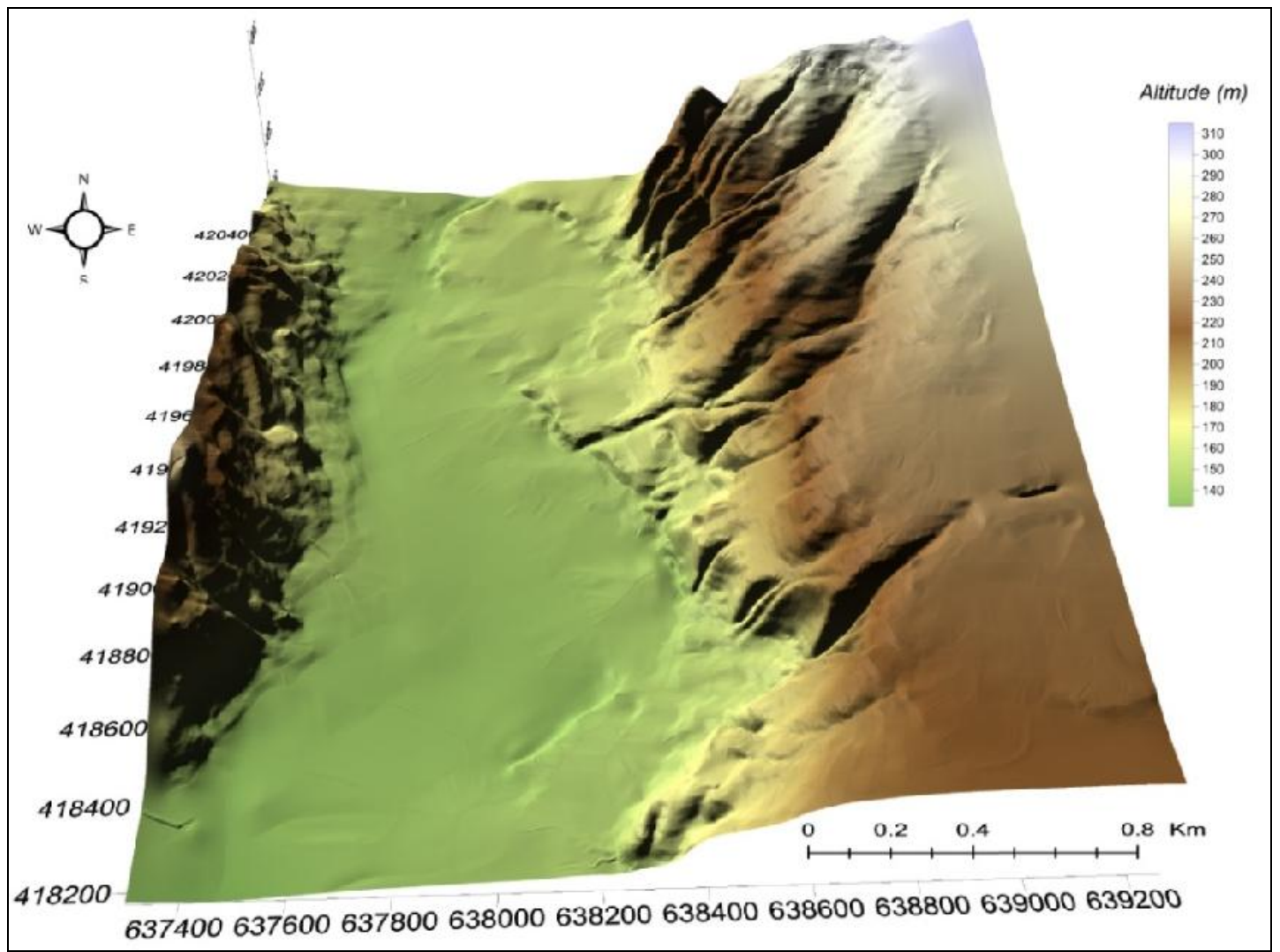

Figure 2. Digital elevation model (3D) for the Cernăteşti locality (1:3 vertical exaggeration). This figure is available in colour online at www.georeview.ro.

Flooded areas were delimited by using the level measurements recorded at the hydrometric station Cernăteşti, on 29 May, when Slănic river had a maximum level value of 1.96 m (Buzău Ialomița Basin Administration). This value was used to obtain the proper flow from analyzed hydrometric station using flow-level correlation chart. Flow values obtained were processed using spatial analysis software Global Mapper 14, where, based on the cross section profile from Cernăteşti hydrometric station was obtained the vertical surface of the water volume (fill surface area), surface corresponding to the obtained flow. The next step was to trace perpendicular profiles on the river bed at an equidistance of $100 \mathrm{~m}$, based on 1:5000 topographic plan (figure 3), methodology used in different specialized studies for delimitation of flooded areas (Șerban \& Bătinaș, 2011). In this case, the profiles were drawn on the appropriate length so that it is obtained values of the volume of water surface in vertical profile similar to the value obtained from hydrometric station Cernăteşti.

This methodology was based on the premise that both upstream and downstream of analyzed hydrometric station the volume of water surface in vertical profile remains approximately the same, as analyzed section has a reduced length (approx. $2 \mathrm{~km}$ ), and intake and / or water loss in this segment are insignificant. Thus, although in horizontal profile there are differences between 
the flooded areas, in vertical profile the water volume surface remains similar in the analyzed segment of the river Slănic, as previously mentioned considerations. Joining the 20 profiles is the last step in delimiting flooded areas.
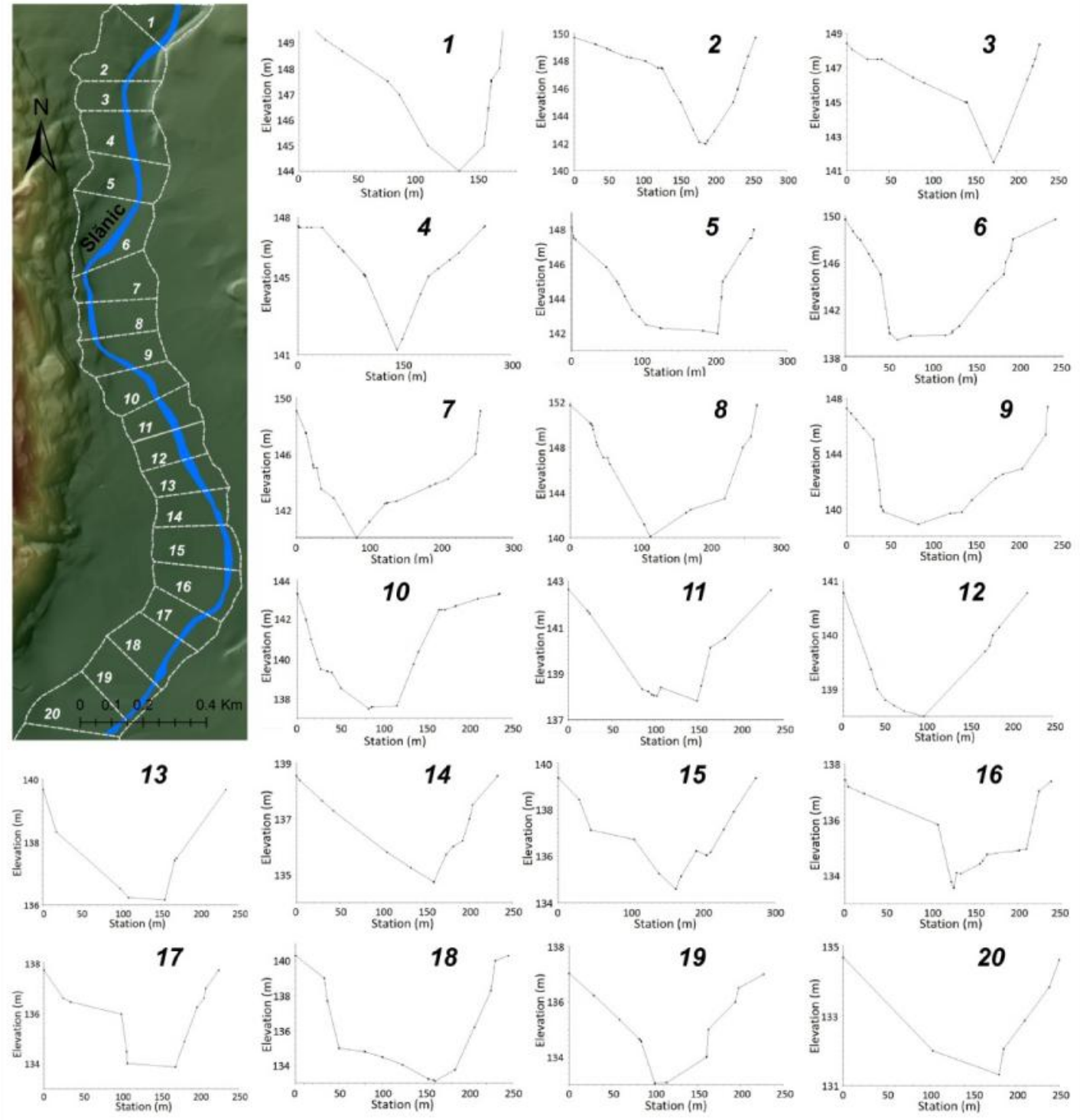

Figure 3. Marking perpendicular profiles for Slănic river bed (100 m equidistance), in order to delimit the flooded area on 29 May, 2012. This figure is available in colour online at www.georeview.ro. 
To delimit the affected socio-economic elements were mapped based on 1:5000 orthophotoplans, 2008 edition, houses and outbuildings, and also access infrastructure from the area of the Cernăteşti locality. Even if many social-economical vulnerbaility to hidric risk phenomena indexes can be found in the specialty literature (Sorocovschi, 2010), the analysis in the present study focuses on a spatial index of vulnerability, obtained by identifying the number of buildings and the accessibility infrastructure (which are considered very important socialeconomical elements) from the study area.

\section{Results and discussions}

The end of May of 2012 meant for the south-eastern Romania a period of intense rainfall causing flash-floods and floods in several areas of rivers. Significant rainfall occurred in May 29 when the core of cold air from altitude shown on the map of relative baric topography between 500-1000 $\mathrm{hPa}$, caused sharp instability of atmosphere (figure 4).

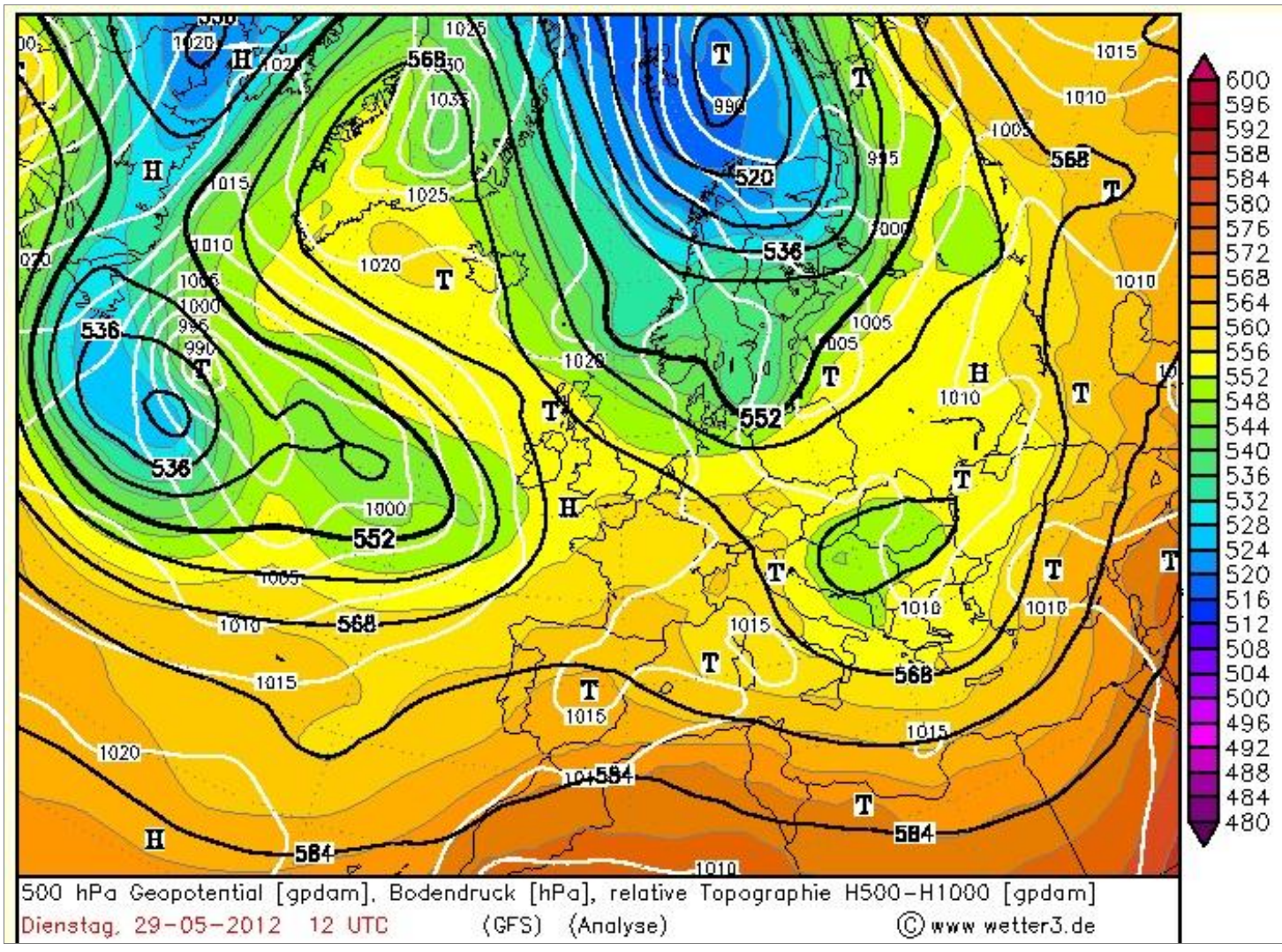

Figure 4. Representation of relative baric topography between 500-1000 hPa on the 29.V.2012 (Source: wetter3.de). This figure is available in colour online at www.georeview.ro.

Thereby the type $\mathrm{Cb}$ convection cells that arose by strong upward convection of warmer air from the ground, generated torrential rains that have come to cumulate $78.2 \mathrm{~mm}$ in the weather station Bisoca, a value that represents approximately $10 \%$ of total average multiannual amount at this station (National Meteorology Administration). 
The high intensity of rainfall recorded on this day, in the Curvature area of Carpathians, generated a flash-flood wave on Slănic river, causing flooding of several households in localities along the river valley. Among these localities was the village Cernăteşti from the lower sector of Slănic, where the flash- floods peak flow of $92.4 \mathrm{~m}^{3} / \mathrm{s}$ and the maximum corresponding level of $136 \mathrm{~cm}$ (reported to the 0-levelling rod level) were occurred at 17 o'clock (figure 6). According to data recorded at the Bisoca meteorological station located in the upper sector of Slănic catchment (figure 1), the maximum hourly amount of rainfall was recorded at 6 o'clock, which was of $22.8 \mathrm{~mm}$ (figure 5).

Liquid flow had a simplistic character (a single top). According to Buzău - Ialomița Basin Administration data, water discharge increased in 11 hours almost 10 times (from $8.36 \mathrm{~m}^{3} / \mathrm{s}$ to 92 $\mathrm{m}^{3} / \mathrm{s}$ ) (figure 5). Until the end of the day, water discharge decreased to $35,6 \mathrm{~m}^{3} / \mathrm{s}$, the decreasing line being slower than the increasing line.
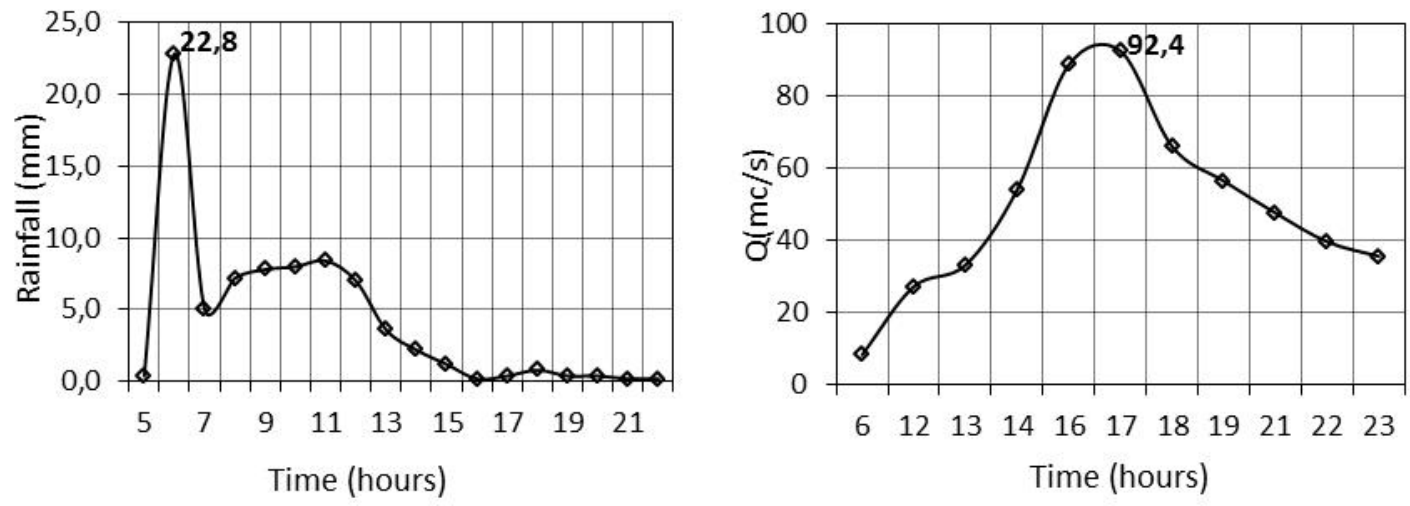

Figure 5. Evolution of hourly rainfall $(\mathrm{mm})$ at the meteorological station Bisoca (right) and hourly water flow $\left(\mathrm{m}^{3} / \mathrm{s}\right)$ at hydrometric station Cernăteşti (left) of $29 \mathrm{~V} 2012$.

The measurements from the day of May 29, 2012, in the Cernăteşti hydrometric station revealed an increase of over 17 times of the level (from $8 \mathrm{~cm}$ to $136 \mathrm{~cm}$, reported in 0-levelling rod level) and over 11 times for the flow of the river (from $8,36 \mathrm{~m}^{3} / \mathrm{s}$ to $92.4 \mathrm{~m}^{3} / \mathrm{s}$ ) between the hours of 6 and 17 (figure 6) the time at which were recorded the maximum values of the two hydrological parameters (Buzău-lalomiţa Basin Administration). Exponential increase in the level of river relative to its flow in the section of Cernăteşti hydrometric station was found and in the correlation chart (figure 6).

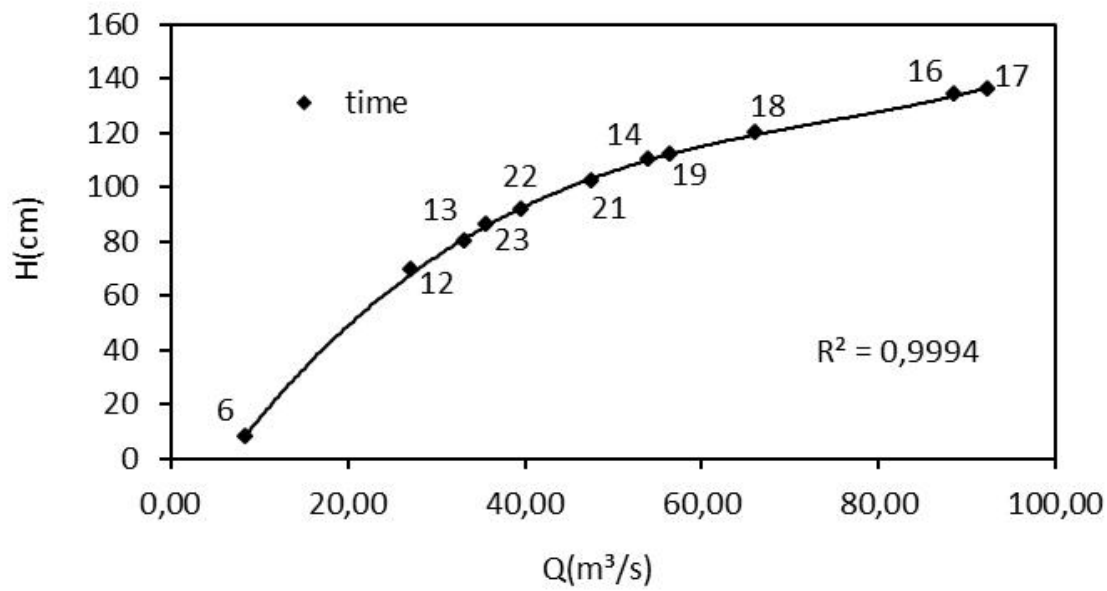


Figure 6. The correlation between the level of the river and the river flow of Slănic river in Cernăteşti on the 29.V.2012.

From the point of view of flooded areas, after applying the above described methodology, was delineated a flooded area (corresponding to the maximum level at 17 o'clock) of approximately 63 ha (figure 6). This area included most of Slănic river valley, where there are constructions and road infrastructure elements. Thus, about 20 constructed elements were flooded (representing almost $3 \%$ of all households in the village) on the left side of the river and a segment of $457 \mathrm{~m}$ of a communal way (figure 7) located on the right side of the river in its flow direction. Other risk elements affected by the flood in 29 May are agricultural lands (usually vegetable) located in the river valley on the left of it (Corine Land Cover, 2006).

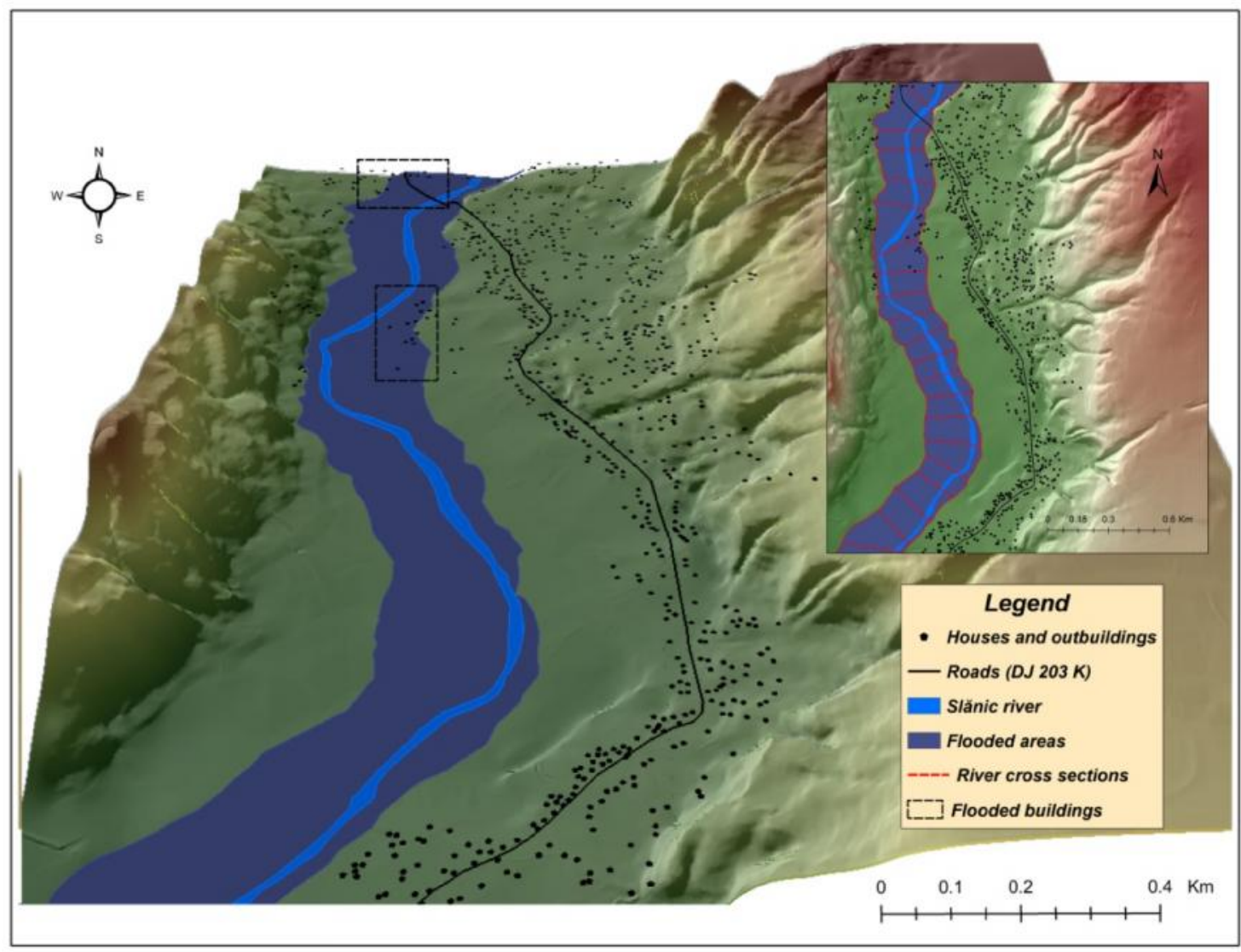

Figure 7. Delimitation based on terrain digital model (scale 1: 5000) of floated areas in the afferent space of the Cernăteşti locality (1:2.5 vertical exaggeration). This figure is available in colour online at www.georeview.ro.

Besides the climatic factor, which produced by its very high intensity the occurrence of a strong flash-flood wave, to the flood formation in the perimeter of Cernăteşti village contributed and the riverbed configuration of Slănic river in this sector. Thus the shallow depth of minor riverbed corroborated with its large width, frequently generate flooding of the river in the major riverbed as a result of flash-flood waves propagated from upstream. 


\section{Conclusions}

The major cause of these hydric risk phenomena is the morphometric and hydrographical peculiarities of Slănic catchment, taken together. These features, combined with extreme weather events such as torrential rains of short duration and high intensity are the triggering prerequisites of the hydrometeorological risk phenomena with great potential for the production of socio-economic damages. Particularly, the conditions of occurrence especially upstream of flash-flood waves (and to a lesser extent the surface runoff on the slopes corresponding to the village Cernăteşti) in the context of strong torrential rains have caused major floods in the lower sector of Slănic catchment, with Cernăteşti locality being among most affected villages in the floodplain of the river. A major cause in the floods formation was represented also by the particularities of the riverbed with large width and low depth in the sector of the studied village.

In these circumstances, is necessary therefore an anthropogenic intervention for the arrangement of Slănic river in highly vulnerable areas, this responsibility belonging to the competent authorities regardless of projection costs involved.

\section{Acknowledgements}

This paper has been financed through the contract POSDRU/86/1.2/S/57462, strategic project "Education and professional training in support of the economic growth and the development of the knowledge-based society", "Quality in the higher education", co-financed by the European Social Fund, through the Sectorial Operational Programme for the Human Resources Development 20072013.

\section{References}

Alfieri L., Thielen J., Pappenberger F. 2012. Ensemble hydro-meteorological simulation for flash flood early detection in southern Switzerland, Journal of Hydrology 424-425: 143-153.

Bilaşco Ş. 2008. Implementarea G.I.S. în modelarea viiturilor de versant, Casa Cărţii de Ştiinţă, Cluj-Napoca.

Costache R., Prăvălie R. 2013. Manifestation potential of surface runoff obtained on the basis of the digital elevation model. Case study: the Subcarpathian sector of Buzău Catchment (in press), Studia Universitatis Babeș-Bolyai.

Drobot R. \& Chendeş V. 2008. Metodologie simplificată pentru identificarea bazinelor generatoare de viituri rapide, Silvologie, vol. VI, Editura Academiei Române, p. 265-284.

Koutroulis A. G., Tsanis I. K. 2010. A method for estimating flash flood peak discharge in a poorly gauged basin. Case study for the 13-14 January 1994 flood, Giofiros basin, Crete, Greece, Journal of Hydrology 385: 150-164.

Looper J. P., Vieux B. E. 2012. An assessment of distributed flash flood forecasting accuracy using radar and rain gauge input for a physics-based distributed hydrologic model, Journal of Hydrology 412-413: 114-132. 
Mătreaţă M. \& Mătreaţă S. 2010. Metodologie de estimare a potenţialului de producere de viituri rapide în bazine hidrografice mici, Comunicări de Geografie, Vol. XIV, Editura Universităţii din Bucureşti, Bucureşti.

Pișota I., Zaharia L., Diaconu D. 2010. Hidrologie, Editia a II-a revizuită și adăugită, Editura Universitară București.

Reed S., Schaake J., Zhang Z. 2007. A distributed hydrologic model and threshold frequencybased method for flash-flood forecasting at ungauged locations, Journal of Hydrology 337: 402-420.

Roo A. D., Barredo J., Lavalle C., Bodis K. and Bonk R. 2007. Potential flood hazard and risk mapping at Pan-European scale, in Digital terrain modelling Development and applications in a policy support environment, Peckham R. J. and Jordan G. (Eds), Springer Berlin Heidelberg, pag. 183-202.

Scrădeanu D., Alexandru Gh. 2007. Hidrogeologie generală, Editura Universităţii din Bucureşti, Bucureşti.

Şerban Gh., Bătinaş R.H. 2011. Iniţiere în G.I.S. şi aplicaţii în Hidrologie. Edit. Presa Universitară Clujeană, ISBN 978-973-595-308-9, Cluj-Napoca.

Sorocovschi V. 2010. Vulnerabilitatea asezarilor rurale. Puncte de vedere, Riscuri si catastrofe, vol VIII, nr. 1.

Teodor S. \& Mătreaţă S. 2011. A way of determining how small river basins of Somes River are susceptible to flash-floods, Carpathian Journal of Earth and Environmental Sciences 6(1): 8998.

Villarini G., Krajewski W. F., Ntelekos A., Georgakakos K. P., Smith J. A. 2010. Towards probabilistic forecasting of flash floods: The combined effects of uncertainty in radar-rainfall and flash flood guidance, Journal of Hydrology 394:275-284.

Zaharia L., Minea G., Toroimac G. I., Barbu R., Sârbu I. 2012. Estimation of the Areas with Accelerated Surface Runoff in the Upper Prahova Watershed (Romanian Carpathians), Balwois, Republic of Macedonia, available on http://ocs.balwois.com/index.php?conference=BALWOIS\&schedConf=BW2012\&page=paper \&op=view\&path\%5B\%5D=595\&path\%5B\%5D=259.

*** 1986, Topographical plan, 1: 5000, Fondul Geodezic Național (National Geodetic Fund).

*** 1990, Corine Land Cover, raster data, European Environment Agency (eea.europa.eu).

*** 2006, Corine Land Cover, raster data, European Environment Agency (eea.europa.eu).

*** 2008, Orthophotomaps, 1:5000 scale, the National Agency of Cadastre and Real Estate Advertising.

*** Buzău - lalomița Basin Administration.

*** National Administration Meteorology.

*** http://www.bluemarblegeo.com/products/global-mapper.php (two weeks free licence).

*** http://www.wetter3.de/archiv/. 